\title{
Crushed sunflower, flax, or canola seeds in lactating dairy cow diets: Effects on methane production, rumen fermentation, and milk production
}

\author{
K. A. Beauchemin, ${ }^{* 1}$ S. M. McGinn, ${ }^{*}$ C. Benchaar, $†$ and L. Holtshausen* \\ ${ }^{*}$ Agriculture and Agri-Food Canada, Lethbridge, Alberta, T1J 4B1, Canada \\ †Dairy and Swine Research and Development Centre, Sherbrooke, Quebec, J1M 1Z3, Canada
}

\begin{abstract}
The objective of this study was to investigate the potential of reducing enteric methane production from dairy cows by incorporating into the diet various sources of long-chain FA varying in their degree of saturation and ruminal availability. The experiment was conducted as a crossover design with 16 lactating dairy cows maintained in 2 groups and fed 4 dietary treatments in four 28-d periods. Eight ruminally cannulated primiparous cows (96 $\pm 18 \mathrm{~d}$ in milk) were assigned to group 1 and 8 multiparous cows $(130 \pm 31 \mathrm{~d}$ in milk) were assigned to group 2 . The dietary treatments were: 1) a commercial source of calcium salts of long-chain fatty acids (CTL), 2) crushed sunflower seeds (SS), 3) crushed flaxseed (FS), and 4) crushed canola seed (CS). The oilseeds added 3.1 to $4.2 \%$ fat to the diet (DM basis). All 3 oilseed treatments decreased methane production $(\mathrm{g} / \mathrm{d})$ by an average of $13 \%$. When corrected for differences in dry matter intake (DMI), compared with CTL, methane production ( $\mathrm{g} / \mathrm{kg}$ of $\mathrm{DM}$ intake) was decreased by feeding FS $(-18 \%)$ or CS $(-16 \%)$ and was only numerically decreased $(-10 \%)$ by feeding SS. However, compared with the CTL, feeding SS or FS lowered digestible DMI by 16 and $9 \%$, respectively, because of lowered digestibility. Thus, only CS lowered methane per unit of digestible DM intake. Feeding SS and CS decreased rumen protozoal counts, but there were no treatment effects on mean ruminal $\mathrm{pH}$ or total volatile fatty acid concentration. Milk efficiency $(3.5 \%$ fat corrected milk/DMI), milk yield, and component yield and concentrations were not affected by oilseed treatments. The study shows that adding sources of long-chain fatty acids to the diet in the form of processed oilseeds can be an effective means of reducing methane emissions. However, for some oilseeds such as SS or FS, the reduction in methane can be at the expense of diet digestibility. The use of crushed CS offers a means of
\end{abstract}

Received November 17, 2008.

Accepted December 17, 2008

${ }^{1}$ Corresponding author: beauchemink@agr.gc.ca mitigating methane without negatively affecting diet digestibility, and hence, milk production.

Key words: flaxseed, canola seed, sunflower seed, methane

\section{INTRODUCTION}

Methane produced by ruminants contributes to enhanced greenhouse gas effect and global warming (IPCC, 2006). Consequently, strategies to mitigate enteric $\mathrm{CH}_{4}$ emissions are currently being explored by several research groups worldwide, as recently reviewed by Beauchemin et al. (2008) and McAllister and Newbold (2008). Enteric $\mathrm{CH}_{4}$ produced during fermentation in the rumen represents an energy loss to the animal; about 2 to $12 \%$ of gross energy intake (GEI) is converted to $\mathrm{CH}_{4}$, depending on the level of feed intake and the composition of the diet (Johnson and Johnson, 1995).

Supplementation of diets with lipids that are not protected from ruminal digestion is one strategy recognized to lower enteric $\mathrm{CH}_{4}$ emissions (Boadi et al., 2004; Monteny et al., 2006). Added fats decrease $\mathrm{CH}_{4}$ emissions by lowering the quantity of OM fermented in the rumen, the activity of ruminal methanogens, and protozoal numbers, and for lipids rich in unsaturated fatty acids (FA), through biohydrogenation of FA (Johnson and Johnson, 1995). However, there appears to be considerable variation in the effects of supplemental fats on $\mathrm{CH}_{4}$ production and only a limited number of studies have been conducted using dairy cows (as summarized by Giger-Reverdin et al., 2003 and Eugène et al., 2008). Reductions in $\mathrm{CH}_{4}$ (g/kg of DMI) have been substantial in some cases: $26 \%$ reduction for extruded flaxseed (FS; Martin et al., 2008; 5.7\% fat added to the dietary DM), 49\% reduction for FS oil (Martin et al., 2008; $5.7 \%$ added fat), and a $27 \%$ reduction for a mixture of sunflower and fish oil (Woodward et al., 2006; 3.8\% added fat). However, other dairy studies have shown no effects (Johnson et al., 2002; 5.6\% added fat from canola seeds and whole cottonseed; Woodward et al., 2006; $2 \%$ added fat from a mixture of FS oil and fish oil). 
The $\mathrm{CH}_{4}$-suppressing effects of supplemental fats may depend upon several factors, including the amount added and the resulting total concentration of fat in the diet, the FA profile of the fat source, the form in which the fat is administered (i.e., either as refined oil or as full-fat oilseeds), and the composition of the diet (high forage vs. high grain). In some cases, added fats lower the intake of ruminally fermented $\mathrm{OM}$ by decreasing DMI, diet digestibility, or both (NRC, 2001) accounting for some of the $\mathrm{CH}_{4}$ suppression. For example, in the study by Martin et al. (2008) the reduction in $\mathrm{CH}_{4}$ caused by feeding extruded FS or FS oil was accompanied by a $14 \%$ reduction in total tract NDF digestibility, and feeding extruded FS reduced DMI by $16 \%$ and feeding FS oil reduced DMI by $26 \%$. Reduction in $\mathrm{CH}_{4}$ production accompanied by lowered digestible DMI may result in lower milk production.

The potential for implementing lipid feeding on commercial dairy farms as a $\mathrm{CH}_{4}$ mitigation strategy is high, because lipid sources are already often added to the diet to increase its energy density (NRC, 2001). Furthermore, feeding fats high in polyunsaturated FA can alter the FA composition of milk (Bu et al., 2007) in a manner beneficial to human health, including increased proportions of monounsaturated FA and polyunsaturated FA and increased concentrations of the conjugated linoleic acid isomer cis-9, trans-11 (Hu and Willett, 2002). However, dairy producers are unlikely to feed supplemental fats to mitigate $\mathrm{CH}_{4}$ until a variety of fat sources are shown to be effective $\mathrm{CH}_{4}$ suppressants in a range of situations, and until effects on milk yield and composition are well established. Hence, the objective of this study was to investigate the effect of supplementing a dairy cow diet with sources of longchain FA varying in their degree of saturation and ruminal availability [including sunflower seeds (SS), FS, and canola seed (CS)] on enteric $\mathrm{CH}_{4}$ emissions and milk production of lactating dairy cows.

\section{MATERIALS AND METHODS}

The experiment was conducted at Agriculture and Agri-Food Canada's Research Centre in Lethbridge, Alberta, Canada. The cows were cared for in accordance with the guidelines of the Canadian Council on Animal Care (1993).

\section{Animals, Experimental Design, and Diets}

The experiment was conducted as a crossover design with 16 lactating dairy cows maintained in 2 groups and fed 4 dietary treatments in four 28-d periods. Eight primiparous cows $(570 \pm 38.4 \mathrm{~kg}$ of BW; $96 \pm 18 \mathrm{DIM})$ that were previously ruminally cannulated (Bar Dia- mond, Parma, ID) were assigned to group 1 and 8 intact multiparous cows $(643 \pm 52 \mathrm{~kg}$ of BW; $130 \pm 31 \mathrm{DIM})$ were assigned to group 2 . Rumen fermentation variables were measured only in group 1 cows. The groups were staggered by 2 wk to simplify measurements.

The dietary treatments were: 1) calcium salts of longchain FA (Enertia, ADM Alliance Nutrition, Quincy, IL; control, CTL), 2) SS, 3) FS, and 4) CS. The oilseeds were added to the diet to provide a theoretical level of 3.3\% added fat (DM basis), based on an initial analysis of a sample of each fat source. The oilseeds were crushed using a roller mill with the roller setting adjusted to ensure the hulls were cracked. The calcium salts of long-chain FA was used as the control because it was assumed to be rumen-inert and would, therefore, have no effect on rumen fermentation or $\mathrm{CH}_{4}$ production.

The diets were formulated using the Cornell-PennMiner System (CPMDairy, Version 3.0.4a; Cornell University, Ithaca, NY; University of Pennsylvania, Kennett Square, PA; and William H. Miner Agricultural Research Institute, Chazy, NY) to provide adequate ME and MP for a $650-\mathrm{kg}$ cow producing $35 \mathrm{~kg}$ of milk/d containing $3.5 \%$ fat and $3.2 \%$ protein. All diets contained steam-rolled barley, a pelleted supplement, and barley silage as the forage source (Table 1). The diets were gradually $(25 \%$ on d $1,50 \%$ on d $2,75 \%$ on d 3) introduced to cows at the start of each period.

\section{Feeding and Management}

The cows had continuous access to water and each TMR was provided for ad libitum intake with at least $10 \%$ of daily feed refusal (as-fed basis). Cows were individually fed 3 times daily at 0600, 1200, and $1730 \mathrm{~h}$ with approximately 10,50 , and $40 \%$ of the total daily feed allocation provided at each feeding, respectively. The forage and concentrates were sampled weekly to determine DM content and the diets were adjusted to account for changes in DM content. Feed offered and refused were measured and recorded daily, and DM content of the TMR and the orts for individual cows was determined weekly to calculate DMI. These samples were then dried at $55^{\circ} \mathrm{C}$, ground to pass a $1-\mathrm{mm}$ screen (standard model 4; Arthur H. Thomas Co., Philadelphia, PA), and stored for subsequent analyses.

The cows were housed in individual tie stalls fitted with rubber mattresses, bedded with wood shavings, and milked twice daily at 0630 and $1630 \mathrm{~h}$. They were turned outside to a drylot for exercise for at least $1 \mathrm{~h}$ daily. Cows were weighed at the start of the experiment and at the end of each period at $1130 \mathrm{~h}$. Milk production was recorded daily throughout the experiment. Milk was sampled during the a.m. and p.m. milking 
Table 1. Ingredient composition of the diets (DM basis)

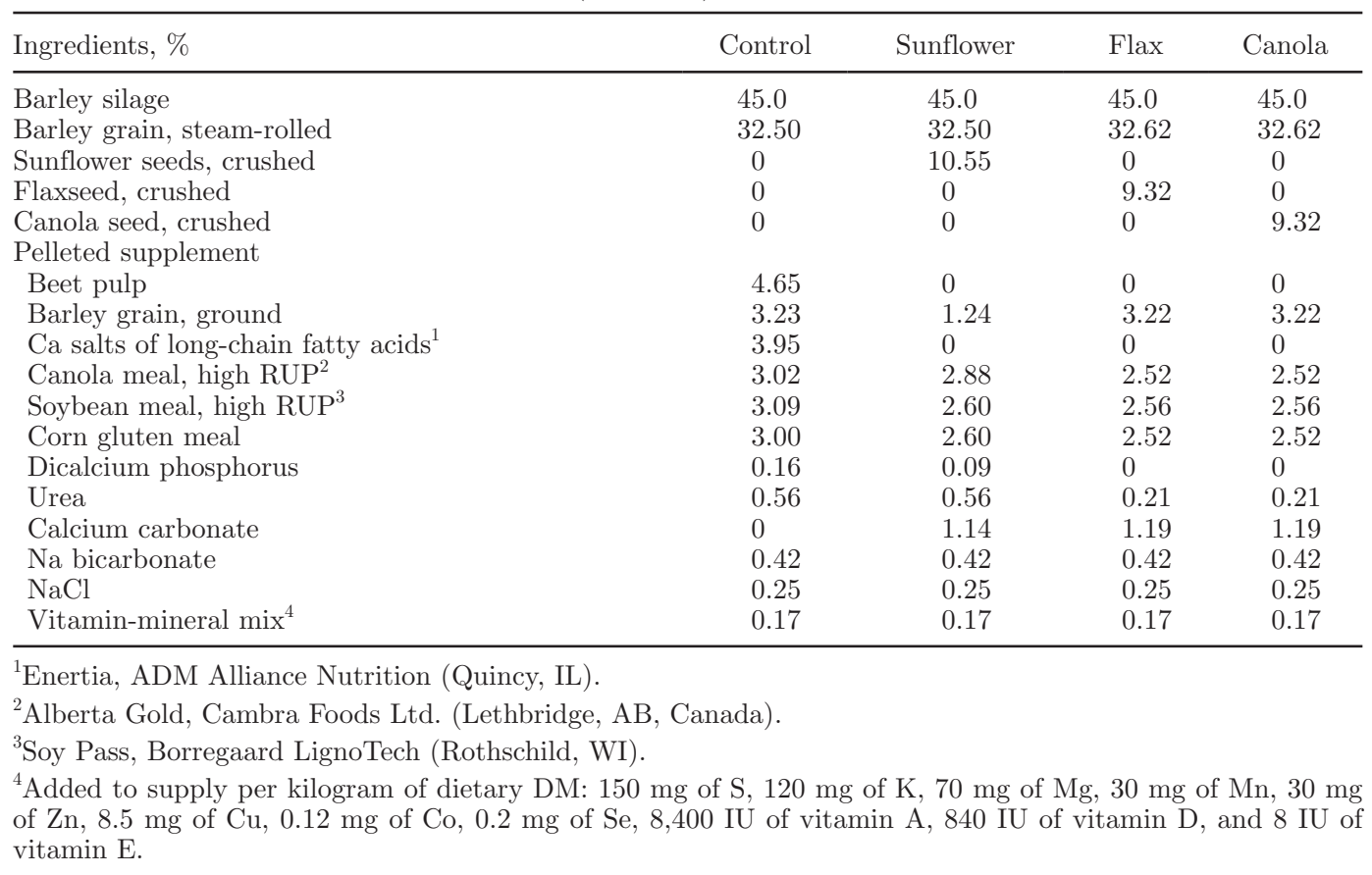

on 3 consecutive days (d 18-20) in each period. Milk samples were preserved with potassium dichromate, stored at $4^{\circ} \mathrm{C}$, and then sent to CanWest DHI (Central Milk Testing Laboratory, Edmonton, Alberta, Canada) for analyses of fat, CP, and lactose (AOAC, 1995) using infrared spectroscopy (MilkoScan 605; Foss Electric, Hillerød, Denmark). Milk composition was corrected for differences in milk volume between a.m. and p.m. milkings.

\section{Digestibility}

Fecal samples (100 g of wet weight) were obtained twice daily from the rectum of each of the 16 cows on the last $5 \mathrm{~d}$ of the period. The samples were pooled for each cow within period and dried at $55^{\circ} \mathrm{C}$ for $48 \mathrm{~h}$ in a forced-draft oven, ground through a $1-\mathrm{mm}$ screen, and analyzed for DM and OM. Samples of the TMR and orts (pooled by cow) were also taken on the same days, dried, and analyzed for DM and OM. Apparent total tract digestibility of DM and OM was determined using indigestible NDF as an internal marker (Cochran et al., 1986). Indigestible NDF content of the TMR, orts, and feces was determined as the NDF residue after 120-h incubation in buffered rumen fluid (DAISY ${ }^{I I}$ Incubator, Ankom Technology, Macedon, NY).

\section{Methane Production}

At the start of the last week of each period, each group of 8 cows (the 2 groups were staggered) was moved to 4 environmental chambers (2 animals/chamber) for measurement of enteric $\mathrm{CH}_{4}$. The cows had been conditioned to the chambers before beginning the experiment. The 2 cows fed the same diet were housed together within a chamber and this pairing was maintained throughout the experiment. Within the chambers, the cows were housed in 2 individual stanchions equipped with feeders. Methane was measured for 3 consecutive days beginning $12 \mathrm{~h}$ after the cows were put into the chambers.

A small positive pressure $(<2 \mathrm{~Pa})$ inside the chamber prevented leakage into the chambers, and the air volume within the chamber was exchanged every $5 \mathrm{~min}$. Flow rates of air in the intake and exhaust ducts were recorded and $\mathrm{CH}_{4}$ concentrations in these ducts were monitored as described by Beauchemin et al. (2007). The difference between the incoming and outgoing mass of $\mathrm{CH}_{4}$ was used to calculate the amount of $\mathrm{CH}_{4}$ generated in each chamber by the 2 cows. The chamber doors were opened twice daily for about 30 min to allow for feeding, cleaning, and milking. When the doors were opened, the corresponding $\mathrm{CH}_{4}$ emissions were omitted. Once the door was closed, the conditions within the chamber stabilized within 5 min. These daily interruptions were accounted for by calculating a mean $\mathrm{CH}_{4}$ emission for the day based on 10-min averages recorded only when the door was closed and the conditions within the chamber stabilized. The chambers were calibrated at the start of each period by releasing a known quantity of $\mathrm{CH}_{4}$ gas, and procedures were adjusted accordingly to obtain $100 \%$ recovery. 
Table 2. Chemical composition of the diets and ingredients (DM basis)

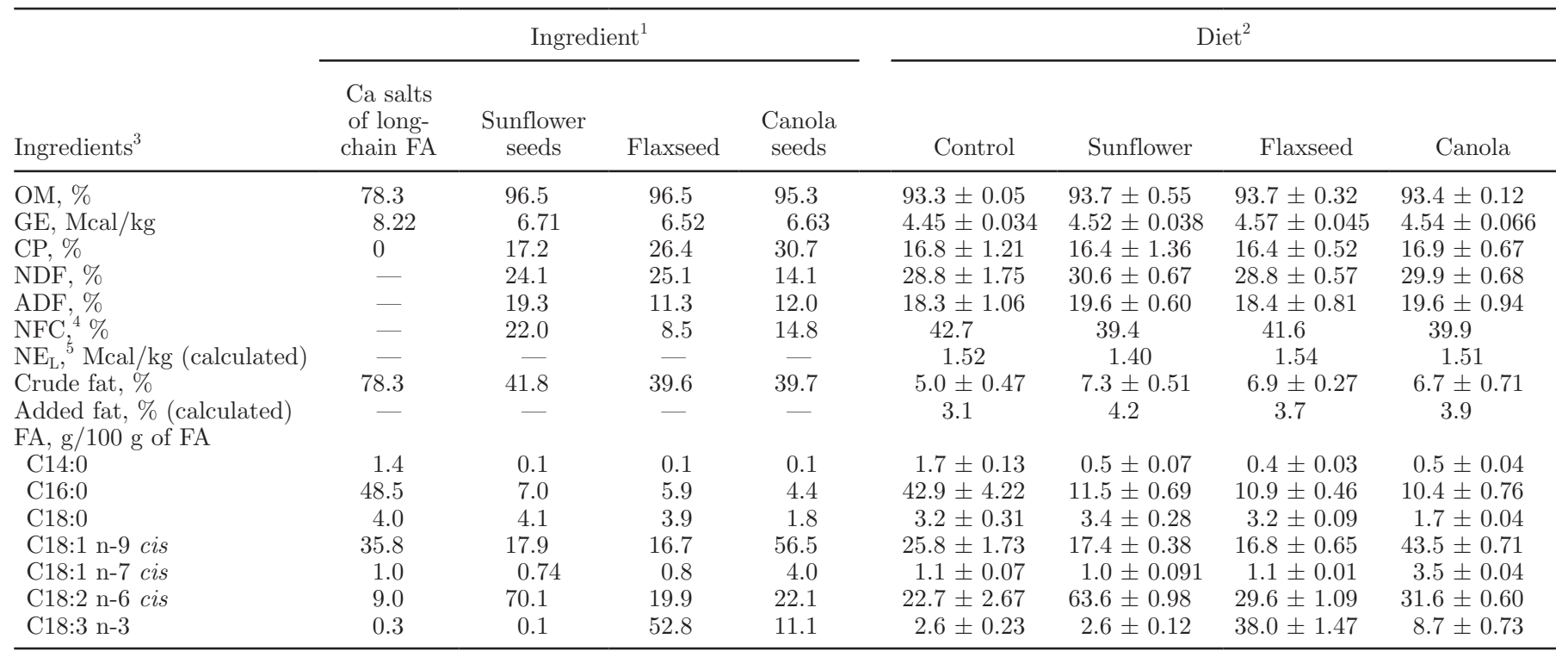

${ }^{1}$ Analysis performed on one composite sample for the study.

${ }^{2}$ Analysis performed on 4 period samples.

${ }^{3} \mathrm{FA}=$ fatty acid; GE $=$ gross energy.

${ }^{4} \mathrm{NFC}=100-\mathrm{CP}-\mathrm{NDF}-$ ether extract - ash.

${ }^{5} \mathrm{The}_{\mathrm{NE}}(\mathrm{Mcal} / \mathrm{kg}$ ) was calculated based on energy output divided by DMI, with energy output determined using the NRC (2001) equations that account for maintenance, milk production, and BW changes.

\section{Ruminal Fermentation and Protozoa}

Ruminal contents were sampled from group 1 cows on d 19 and 21 of each period. Samples were taken at 0 and $4 \mathrm{~h}$ after the morning feeding to measure ruminal fermentation characteristics $\left(\mathrm{pH}, \mathrm{NH}_{3}-\mathrm{N}\right.$, and VFA) and protozoal counts (4-h sample only). Approximately $0.5 \mathrm{~L}$ of ruminal contents was obtained from multiple sites within the rumen and strained through a PECAP polyester screen (pore size $355 \mu \mathrm{m}$; B \& S H Thompson, Ville Mont-Royal, Quebec, Canada). The ruminal $\mathrm{pH}$ of the filtered ruminal fluid was measured within 5 min using a pH meter (Accumet model 25, Denver Instrument Company, Arvada, CO). Five milliliters of the filtered ruminal fluid was added to $1 \mathrm{~mL}$ of $1 \%$ sulfuric acid and samples were retained for $\mathrm{NH}_{3}-\mathrm{N}$ determination. Another $5 \mathrm{~mL}$ of the filtered ruminal fluid was added to $1 \mathrm{~mL}$ of $25 \%$ meta-phosphoric acid and samples were retained for VFA determination. These samples were stored at $-20^{\circ} \mathrm{C}$ until analyzed. In addition, $5 \mathrm{~mL}$ of strained ruminal fluid was preserved with $5 \mathrm{~mL}$ of methyl green-formalin-saline solution (1:1, vol/ vol) and stored in darkness at room temperature for protozoa enumeration.

\section{Chemical Analyses}

All chemical analyses were performed on each sample in duplicate, and where the coefficient of variation was
$>5 \%$, the analysis was repeated. Analytical DM was determined by drying the oven-dried samples at $135^{\circ} \mathrm{C}$ for $2 \mathrm{~h}$, followed by hot weighing (AOAC, 1995; method 930.05). The OM content was calculated as the difference between 100 and the percentage ash (AOAC, 1995; method 942). Gross energy was determined using an adiabatic calorimeter (model 1241, Parr, Moline, IL). The NDF was determined as described by Van Soest et al. (1991) using heat-stable $\alpha$-amylase (Termamyl 120L, Novo Nordisk Biochem, Franklinton, NC) and sodium sulfite, and ADF was determined according to AOAC (1995; method 973.18). For the measurement of $\mathrm{CP}(\mathrm{N} \times 6.25)$, samples were ground using a ball mill (Mixer Mill MM2000, Retsch, Haan, Germany) to a fine powder and total $\mathrm{N}$ was quantified by flash combustion and thermal conductivity detection (Carlo Erba Instruments, Milan, Italy). Lipids were extracted from fat sources and diets using a Soxtec system HT6 apparatus (Tecator, Fisher Scientific, Montreal, QC, Canada) according to AOAC (1995, method no. 7.060). Concentration of lipid was determined by combustion of the extracted $\mathrm{OM}$ at $550^{\circ} \mathrm{C}$ overnight in a muffle furnace (AOAC, 1995).

Ruminal VFA were quantified using a gas chromatograph (model 5890, Hewlett-Packard Lab, Palo Alto, CA) with a capillary column $(30 \mathrm{~m} \times 0.32 \mathrm{~mm}$ i.d., $1-\mu \mathrm{m}$ phase thickness, Zebron ZB-FAAP, Phenomenex, Torrance, $\mathrm{CA}$ ), and flame ionization detection. The 
Table 3. Effect of fat source on body weight, intake, and digestibility of lactating dairy cows $(\mathrm{n}=16)$

\begin{tabular}{lccccc}
\hline & \multicolumn{4}{c}{ Dietary treatment $^{1}$} \\
\cline { 2 - 4 } Item & Control & Sunflower & Flax & Canola & SE \\
\hline Mean BW, kg & 616 & 623 & 619 & 619 & 19.4 \\
BW change, g/d & $195^{\text {bc }}$ & $-6.51^{\mathrm{c}}$ & $270^{\mathrm{ab}}$ & $510^{\mathrm{a}}$ & 168.4 \\
DMI, kg/d & $18.7^{\mathrm{c}}$ & $19.5^{\mathrm{ab}}$ & $19.0^{\mathrm{bc}}$ & $20.1^{\mathrm{a}}$ & 0.61 \\
DM digestibility, \% & $61.3^{\mathrm{a}}$ & $49.2^{\mathrm{c}}$ & $55.2^{\mathrm{b}}$ & $61.6^{\mathrm{a}}$ & 1.75 \\
OM digestibility, \% & $63.5^{\mathrm{a}}$ & $52.0^{\mathrm{c}}$ & $58.1^{\mathrm{b}}$ & $64.3^{\mathrm{a}}$ & 1.67 \\
Digestible DMI, kg/d & $11.6^{\mathrm{a}}$ & $9.8^{\mathrm{b}}$ & $10.5^{\mathrm{b}}$ & $12.5^{\mathrm{a}}$ & 0.47 \\
\hline
\end{tabular}

${ }^{\mathrm{a}-\mathrm{c}}$ Within a row, means that do not have a common superscript differ, $P<0.05$.

${ }^{1}$ Crushed oilseeds were added to the diet to provide $3.7 \%$ added fat. For the control diet, Ca salts of long-chain fatty acids were added (Enertia, ADM Alliance Nutrition, Quincy, IL).

oven temperature was $170^{\circ} \mathrm{C}$ held for 4 min, which was then increased by $5^{\circ} \mathrm{C} / \mathrm{min}$ to $185^{\circ} \mathrm{C}$, and then by $3^{\circ} \mathrm{C} /$ min to $220^{\circ} \mathrm{C}$, and held at this temperature for $1 \mathrm{~min}$. The injector temperature was $225^{\circ} \mathrm{C}$, the detector temperature was $250^{\circ} \mathrm{C}$, and the carrier gas was helium. Concentration of $\mathrm{NH}_{3}-\mathrm{N}$ in the ruminal contents was determined as described by Rhine et al. (1998). Ruminal protozoa were counted using a Fuchs-Rosenthal counting chamber (Hausser Scientific Partnership, Horsham, PA) as described by Ogimoto and Imai (1981). Duplicate preparations of each sample were counted, and if either value differed from the average by more than $10 \%$, the counts were repeated.

\section{Calculations and Statistical Analysis}

Data for intake, milk production, and $\mathrm{CH}_{4}$ for each cow were summarized by day. Data for rumen fermentation were summarized by hour within sampling day, and digestibility and BW data were summarized by period. Data for protozoa were $\log _{10}$ transformed before analysis, with the inverse $\log _{10}$ least squares means reported. Digestible DMI was calculated for each cow using mean DMI and the corresponding digestibility coefficient for each period.

Analysis of variance was conducted using the Mixed procedure of SAS (SAS Institute, 2001). Cow served as the experimental unit for all data except $\mathrm{CH}_{4}$ production, for which chamber was the experimental unit. The model for the intake and milk variables included the fixed effects of group, treatment, day, and their interactions, with cow within group and period within group designated as random effects. The effect of day was included as a repeated measure. The data for BW were analyzed using the same model, but without the effect of day. Rumen fermentation data were analyzed using a model that included the fixed effects of treatment, day, hour, and all interactions, and the random effects of cow and period. Day and hour were included as repeated measures. The $\mathrm{CH}_{4}$ data were analyzed using a model that included the fixed effects group, treatment, day, and their interaction, with chamber within group and period within group designated as random variables. The effect of day was included as a repeated

Table 4. Effects of fat source on methane emissions from lactating dairy cows $(n=8 \text { pairs of cows })^{1}$

\begin{tabular}{|c|c|c|c|c|c|}
\hline \multirow[b]{2}{*}{ Item } & \multicolumn{4}{|c|}{ Dietary treatment ${ }^{2}$} & \multirow[b]{2}{*}{ SEM } \\
\hline & Control & Sunflower & Flaxseed & Canola & \\
\hline DMI, $\mathrm{kg} / \mathrm{d}$ & $18.1^{\mathrm{b}}$ & $18.2^{\mathrm{b}}$ & $18.0^{\mathrm{b}}$ & $19.4^{\mathrm{a}}$ & 0.54 \\
\hline \multicolumn{6}{|l|}{ Methane } \\
\hline $\mathrm{g} /($ animal·d $)$ & $293^{\mathrm{a}}$ & $264^{\mathrm{b}}$ & $241^{\mathrm{b}}$ & $265^{\mathrm{b}}$ & 19.3 \\
\hline $\mathrm{g} / \mathrm{kg}$ of $\mathrm{DMI}^{3}$ & $16.3^{\mathrm{a}}$ & $14.6^{\mathrm{ab}}$ & $13.4^{\mathrm{b}}$ & $13.7^{\mathrm{b}}$ & 0.94 \\
\hline$\%$ of GE intake & $4.9^{\mathrm{a}}$ & $4.3^{\mathrm{ab}}$ & $3.9^{\mathrm{b}}$ & $4.0^{\mathrm{b}}$ & 0.30 \\
\hline $\mathrm{g} / \mathrm{kg}$ of digestible $\mathrm{DMI}^{4}$ & $26.6^{\mathrm{b}}$ & $29.7^{\mathrm{a}}$ & $24.2^{\mathrm{bc}}$ & $22.3^{\mathrm{c}}$ & 1.79 \\
\hline $\mathrm{g} / \mathrm{kg}$ of $\mathrm{FCM}$ & $12.4^{\mathrm{a}}$ & $11.7^{\mathrm{a}}$ & $10.5^{\mathrm{b}}$ & $11.4^{\mathrm{a}}$ & 1.21 \\
\hline
\end{tabular}

${ }^{\mathrm{a}-\mathrm{c}}$ Within a row, means that do not have a common superscript differ, $P<0.05$.

${ }^{1}$ Methane emissions and corresponding DMI determined for $3 \mathrm{~d}$ during which the animals were in the chambers.

${ }^{2}$ Crushed oilseeds were added to the diet to provide $3.7 \%$ added fat. For the control diet, Ca salts of long-chain fatty acids were added (Enertia, ADM Alliance Nutrition, Quincy, IL).

${ }^{3}$ Sunflower seed vs. control, $P=0.098$.

${ }^{4}$ Flaxseed vs. control, $P=0.104$. 
Table 5. Effect of fat source on ruminal fermentation characteristics of lactating dairy cows $(\mathrm{n}=16)$

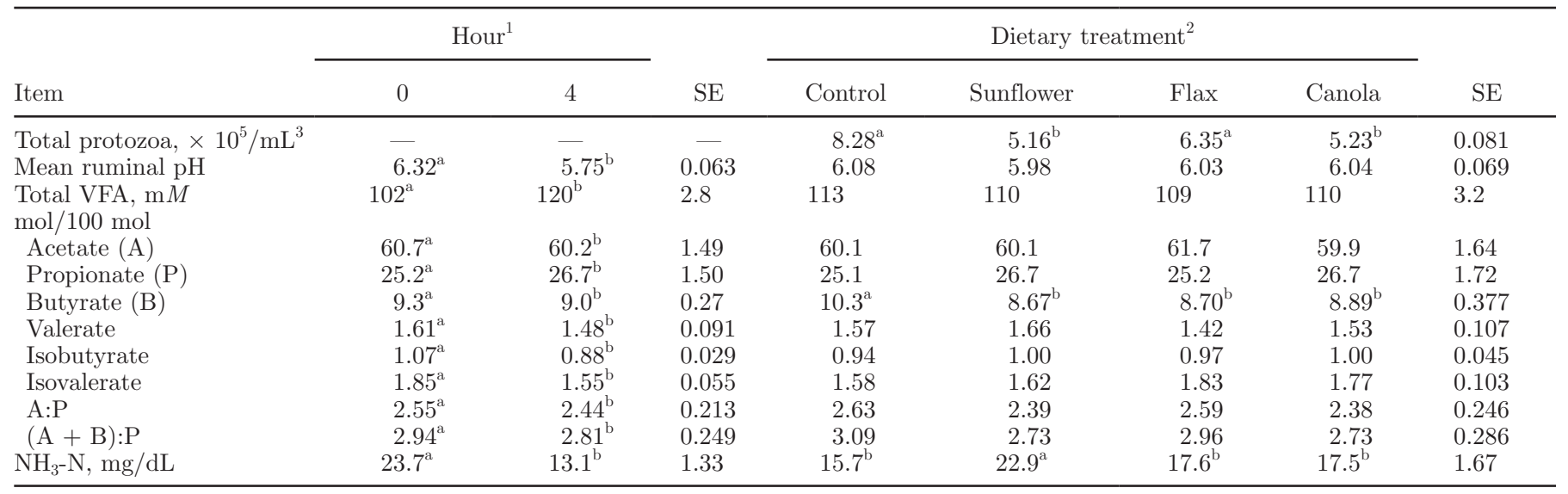

${ }^{\mathrm{a}, \mathrm{b}}$ Within a row and heading, means that do not have a common superscript differ, $P<0.05$. No hour $\times$ treatment interactions were found for any of the variables listed.

${ }^{1}$ Hour after feeding.

${ }^{2}$ Crushed oilseeds were added to the diet to provide $3.7 \%$ added fat. For the control diet, Ca salts of long-chain fatty acids were added (Enertia, ADM Alliance Nutrition, Quincy, IL).

${ }^{3}$ Protozoa were only counted in samples taken at $4 \mathrm{~h}$ after feeding.

measurement. For the repeated measures, various covariance structures were tried, with the final choice depending on low values for the Akaike's information criteria. Degrees of freedom were estimated with the Kenward-Roger specification in the model. Treatment effects were declared significant at $P<0.05$, and means were compared using contrasts. Least squares means are reported throughout.

\section{RESULTS}

The diets were formulated to provide $3.3 \%$ added fat based on a preliminary analysis of the fat sources. However, the actual fat content of the samples collected during the experiment indicated that the Ca salts of long-chain FA contained slightly less fat than expected while the oilseeds were higher in fat content than expected. Consequently, the amount of added fat averaged $3.7 \%$ of dietary DM, ranging from $3.1 \%$ for CTL to $4.2 \%$ for SS (Table 2). Total fat content of the diets averaged $6.5 \%$ (5.1 to $7.3 \%$ ) of DM.

Of the various oilseeds fed, only CS resulted in similar intakes of digestible DM compared with the CTL (Table 3). Although feeding SS or CS increased DMI compared with the CTL, feeding SS or FS decreased DM digestibility by $20 \%$ and $10 \%$, respectively. The net effect was that digestible DMI was $16 \%$ lower for SS and $9 \%$ lower for FS than for CTL, whereas it was similar for CS and CTL.

All 3 oilseed treatments lowered $\mathrm{CH}_{4}$ production (g/d); a 10\% decrease occurred for SS and CS and an $18 \%$ decrease occurred for FS (Table 4). When cor-

Table 6. Effect of fat source on milk production of lactating dairy cows $(\mathrm{n}=16)$

\begin{tabular}{lccccc}
\hline & \multicolumn{5}{c}{ Dietary treatment $^{1}$} \\
\cline { 2 - 4 } & Control & $\begin{array}{c}\text { Sunflower } \\
\text { seeds }\end{array}$ & Flaxseed & Canola seeds & SE \\
\hline Item & & & & & \\
Yield, kg/d & 26.6 & 26.7 & 26.8 & 27.0 & 1.67 \\
Milk & 24.2 & 23.3 & 23.5 & 23.7 & 1.38 \\
3.5\% FCM & 0.84 & 0.79 & 0.81 & 0.82 & 0.055 \\
Fat & 0.87 & 0.86 & 0.86 & 0.88 & 0.051 \\
Protein & 1.23 & 1.22 & 1.21 & 1.24 & 0.084 \\
Lactose & & & & & \\
Components, \% & 3.24 & 3.09 & 3.22 & 3.16 & 0.192 \\
Fat & 3.25 & 3.29 & 3.35 & 3.31 & 0.069 \\
Protein & 4.55 & 4.61 & 4.62 & 4.58 & 0.057 \\
Lactose & 1.35 & 1.27 & 1.30 & 1.26 & 0.101 \\
Milk efficiency, $\mathrm{kg}$ of 3.5\% FCM/kg of DMI & 1.35 &
\end{tabular}

${ }^{1}$ Fat sources were added to the diet to provide $3.7 \%$ added fat. For the control diet, Ca salts of long-chain fatty acids were added (Enertia, ADM Alliance Nutrition, Quincy, IL). There were no differences among means within each row, $P<0.05$. 
rected for differences in DMI, compared with CTL, $\mathrm{CH}_{4}$ production decreased by feeding FS $(-18 \%)$ or CS $(-16 \%)$ and tended to decrease $(-10 \% ; P=0.098)$ by feeding SS. Methane production expressed as a percentage of GEI was not changed by the addition of SS in the diet, but was $20 \%$ lower for FS and $17.5 \%$ lower for CS, compared with CTL. However, only CS actually lowered $\mathrm{CH}_{4}$ production when expressed on the basis of digestible DMI, with FS only tending $(P=0.104)$ to lower $\mathrm{CH}_{4}$ per kilogram of digestible DMI.

Means for the rumen fermentation variables are given by hour and treatment because the effects of hour were statistically significant for most of the variables (Table $5)$. However, there were no hour $\times$ treatment interactions for any of the fermentation variables. Feeding SS and CS decreased rumen total protozoal counts, whereas feeding FS only numerically $(P=0.12)$ decreased counts compared with CTL. For all diets, about $99 \%$ of the protozoa were entodiniomorphs. There were no effects of treatment on mean ruminal $\mathrm{pH}$ or total VFA concentration and the only individual VFA concentration affected was butyrate, which was lowered for all 3 oilseed treatments. Rumen $\mathrm{NH}_{3}-\mathrm{N}$ concentration was higher for SS compared with the other treatments, with no differences between CTL, FS, and CS.

Milk yield, component yield, and milk component concentrations were not affected by oilseed treatments (Table 6). Similarly, milk efficiency (kg of 3.5\% FCM/ $\mathrm{kg}$ of DMI) was not affected by treatment.

\section{DISCUSSION}

Inventories of enteric $\mathrm{CH}_{4}$ emissions from the livestock sectors are calculated in many countries using the Intergovernmental Panel on Climate Change Tier 2 methodology (IPCC, 2006), which calculates $\mathrm{CH}_{4}$ emissions as a percentage of GEI. A default $\mathrm{CH}_{4}$ conversion rate of $6.5 \pm 1 \%$ is used for dairy cattle. However, $\mathrm{CH}_{4}$ conversion rates for dairy cows fed in North America may be lower than this default value (e.g., $4.7 \%$ of GEI; Johnson et al., 2002). Recently, Kebreab et al. (2008) used diet-specific mechanistic models to predict $\mathrm{CH}_{4}$ conversion rates for dairy cows fed diets typical of those used in various regions of the United States. They reported an average $\mathrm{CH}_{4}$ conversion rate of $5.63 \%$ of GEI, ranging from 3.78 to $7.43 \%$. The mean values for our study (3.87-4.87\%) are well within this range.

Our study examined the potential of reducing enteric $\mathrm{CH}_{4}$ emissions from lactating dairy cows by adding oilseed to the diet that supplied long-chain FA varying in their degree of saturation and ruminal availability. A commercial source of calcium salts of long-chain FA, assumed to be rumen inert, was used in the control diet so that treatment effects were not caused by an increase in the fat content of the diet. It was assumed that the commercial fat source had no effect on methanogenesis relative to a diet without supplemental fat, which may not have been entirely the case. Dohme et al. (2000) used a rumen simulation technique and showed that compared with no added fat, adding $8.1 \%$ of the dietary DM as calcium salts of long-chain FA lowered $\mathrm{CH}_{4}$ emissions by $5.4 \%$, because of a decrease in $\mathrm{OM}$ fermented in the rumen. Although the diet was supplemented with a lower concentration of fat in our study, it is possible that the $\mathrm{CH}_{4}$-suppressing effects of the oilseeds would have been greater had a control diet without added fat been used.

All 3 oilseeds were processed before feeding to maximize rumen availability. Sunflower seeds, FS, and CS were chosen because they are readily available to dairy producers in western Canada and they range in FA profiles. The CS were high in C18:1 (60\% of total FA), the SS were high in C18:2 (70\%), and the FS were high in C18:3 (53\%; Table 2). In contrast, the rumen inert fat was high in C16:0 (48.5\%) and C18:1 (36\%). The fat sources were added to the diet to supply $3.3 \%$ fat. This level of added fat was chosen to maximize $\mathrm{CH}_{4}$ abatement, while minimizing potentially detrimental effects on feed digestibility or intake (NRC, 2001). However, the actual amount of fat (3.7\%) added to the diets was higher than expected, because the Ca salts of long-chain FA contained slightly less fat, and the oilseeds contained slightly more fat, than was expected. Nevertheless, the level of fat in the CTL, FS, and CS diets were within the NRC (2001) recommendation for dairy diets, that is, an upper limit of 3 to $4 \%$ added fat and 6 to $7 \%$ total fat in the dietary DM. The SS diet slightly exceeded this recommendation at $4.2 \%$ added fat and $7.3 \%$ total fat.

Compared with the CTL diet, feeding oilseeds reduced enteric $\mathrm{CH}_{4}$ emissions (g/d) by an average of $13 \%$, with no differences among oilseeds. Because $\mathrm{CH}_{4}$ production is proportional to DMI (Giger-Reverdin et al., 2003; Grainger et al., 2007), emissions are often expressed on the basis of intake. Accounting for differences in intake revealed that SS were less effective suppressants of $\mathrm{CH}_{4}$ production than the other oilseeds; SS tended to reduce $(P=0.098) \mathrm{CH}_{4}(\mathrm{~g} / \mathrm{kg}$ of DMI) by $10 \%$ compared with the CTL, whereas FS and CS reduced $\mathrm{CH}_{4}(\mathrm{~g} / \mathrm{kg}$ of DMI) by 16 to $18 \%$.

Our study shows that all 3 oilseeds reduced $\mathrm{CH}_{4}$ production when added to a diet to supply a similar concentration of added fat; however SS were less effective than FS and CS. The reduced effectiveness of SS for reducing $\mathrm{CH}_{4}$ production was unexpected. It has been suggested that the effectiveness of FA sources in 
lowering $\mathrm{CH}_{4}$ (g/ $\mathrm{kg}$ of DMI) is inversely proportional to degree of saturation of the FA (Giger-Reverdin et al., 2003). If so, CS, not SS, should have been least effective. In a previous study with beef cattle, SS, sunflower oil, and tallow were equally effective in reducing $\mathrm{CH}_{4}$ (g/kg of DMI; Beauchemin et al., 2007), indicating that the FA profile of fats may have little effect on $\mathrm{CH}_{4}$ emissions, whereas form of the fat and its rumen availability are likely highly important (Martin et al., 2008). Johnson and Johnson (1995) suggested that although biohydrogenation of FA in the rumen competes with methanogenesis for hydrogen, differences in intake of saturated and unsaturated FA by the cows fed supplemental fats would likely be too small to detect differences in $\mathrm{CH}_{4}$ production caused by biohydrogenation of FA. In agreement with Johnson and Johnson (1995), Woodward et al. (2006) did a stoichiometric calculation showing that the biohydrogenation of flaxseed oil would only reduce enteric $\mathrm{CH}_{4}$ by about $13 \mathrm{~g} / \mathrm{d}$ (or about $5 \%$ of the $\mathrm{CH}_{4}$ emissions).

In reviewing the literature where sources of longchain FA have been used for $\mathrm{CH}_{4}$ abatement, it is clear the responses have been variable. When dairy cows that were fed a restricted level of DMI were offered an additional $2.7 \mathrm{~kg}$ of whole cottonseed/d (adding $3.3 \%$ fat to the dietary DM), $\mathrm{CH}_{4}$ emissions ( $\mathrm{g} / \mathrm{kg}$ of DMI) were reduced by $26 \%$ (Grainger et al., 2008). Martin et al. (2008) fed various forms of FS (5.7\% added fat) to dairy cow diets and reported a 10\% reduction in $\mathrm{CH}_{4}$ (g/kg of DMI) for unprocessed seeds, a $26 \%$ reduction for extruded seeds, and a $49 \%$ reduction for crude oil. Woodward et al. (2006) fed $3.75 \%$ of DMI as a mixture of sunflower and fish oil and observed a $27 \%$ reduction in $\mathrm{CH}_{4}(\mathrm{~g} / \mathrm{kg}$ of DMI) with no effects on DMI or milk yield. McGinn et al. (2004) added 5\% sunflower oil to a forage-based diet fed to beef cattle and reduced $\mathrm{CH}_{4}$ (g/kg of DMI) by $17 \%$. Beauchemin et al. (2007) added tallow, sunflower oil, and whole sunflower seeds $(3.4 \%$ added fat) to a forage-based diet fed to beef cattle and observed a $15 \%$ reduction in $\mathrm{CH}_{4}(\mathrm{~g} / \mathrm{kg}$ of DMI) and a reduction in $\mathrm{CH}_{4}$ /digestible DMI ranging from 9.9 (tallow) to $18.8 \%$ (SS).

However, other studies have shown no effects of added fat on $\mathrm{CH}_{4}$ production. Johnson et al. (2002) added up to $5.6 \%$ fat from a mixture of CS and whole cottonseed to the diet of dairy cows and observed no reduction in $\mathrm{CH}_{4}$ when measured every 3 mo over an entire lactation. Woodward et al. (2006) fed dairy cows on pasture a mixture of flaxseed oil and fish oil (added at $2 \%$ of DMI), and observed no effect on $\mathrm{CH}_{4}$ when measured after 3 mo of feeding. The reason for the lack of $\mathrm{CH}_{4}$ response to supplemental fats in some studies is not clear, but it is possible that there is an adaptation of the rumen methanogens over time. It is not clear whether the effects of added fat on $\mathrm{CH}_{4}$ suppression are maintained over the long term, as many of the studies have been short term.

The reductions in $\mathrm{CH}_{4}(\mathrm{~g} / \mathrm{kg}$ of DMI) per unit of added fat observed in our study (2.5\% for SS, $4.9 \%$ for FS, and $4.1 \%$ for CS) are lower than the results of a meta-analysis conducted by Beauchemin et al. (2008), in which $\mathrm{CH}_{4}$ was reduced in ruminants by $5.6 \%$ with each percentage unit addition of supplemental fat. That study included a broad range of experimental conditions including different fat sources, levels of added fat, animal species, level of intake, and diet composition. However, almost all of the studies compared the effects of the added fat sources to a control diet without added fat rather than a control diet with added inert fat, as was used in the present study. Furthermore, only 4 of the 17 studies used dairy cows (Johnson et al., 2002; 2 studies from Woodward et al., 2006; Grainger et al., 2008) and highly effective medium-chain fatty acid sources such as coconut oil (Machmüller and Kreuzer, 1999) and pure myristic acid (Machmüller et al., 2003) were included in the data set. In an analysis of data from 7 dairy cow studies, Giger-Reverdin et al. (2003) reported that $\mathrm{CH}_{4}(\mathrm{~g} / \mathrm{kg}$ of DMI) was reduced by $2.3 \%$ with each $1 \%$ addition of fat. In another analysis of dairy cow data, Eugène et al. (2008) reported a 2.3\% decrease in $\mathrm{CH}_{4}(\mathrm{~g} / \mathrm{d})$ per $1 \%$ addition of fat, but no decrease in $\mathrm{CH}_{4}$ when expressed on the basis of intake (g/ $\mathrm{kg}$ of DMI) indicating that the $\mathrm{CH}_{4}$ suppression in those studies was caused by lower intakes of cows fed diets with added fat.

Examination of the literature clearly indicates that supplemental fats can reduce $\mathrm{CH}_{4}$ emissions, but in many cases the $\mathrm{CH}_{4}$ suppressing effects are caused by a decrease in DMI (Eugène et al., 2008), a decrease in ration digestibility (Martin et al., 2008), or both (Hess et al., 2008; Martin et al., 2008). In our study, emissions were expressed on the basis of digestible DMI $(\mathrm{g} / \mathrm{kg}$ of digestible DMI) to account for this possibility. The analysis revealed that the effect of SS on lowering emissions was entirely caused by a reduction in digestible DMI; for FS, $\mathrm{CH}_{4}$ suppression was partially caused by a decrease in digestible DMI. In contrast, none of the $\mathrm{CH}_{4}$ suppression observed with CS was attributed to effects on digestibility or intake. The extent of the decrease in diet digestibility with added SS was somewhat unexpected. Previously we fed (8.9\% of DMI) SS to beef cattle receiving a forage based diet and observed slightly reduced DM digestibility, but $\mathrm{CH}_{4}$ per unit of digestible DMI was still less than the control (Beauchemin et 
al., 2007). Furthermore, Finn et al. (1985) reported no effects on digestibility when dairy cows were fed rolled SS $(9.7 \%$ of DMI).

Feeding FS also reduced DM digestibility, but the reduction in $\mathrm{CH}_{4}$ production was not solely caused by reduced digestibility. A similar effect for FS was reported by Martin et al. (2008); feeding extruded FS decreased DM digestibility, but $\mathrm{CH}_{4}$ per unit of digestible OM was still reduced by $22 \%$. In our study, CS had the advantage of lowering $\mathrm{CH}_{4}$ production $(\mathrm{g} / \mathrm{d}, \mathrm{g} / \mathrm{kg}$ of DMI) without lowering DMI or digestibility.

Lower protozoal counts when feeding oilseeds have been reported previously when feeding unsaturated FA (Ivan et al., 2004). Rumen methanogens exist on the surface of ciliate protozoa and account for between 9 and $37 \%$ of enteric $\mathrm{CH}_{4}$ production (McAllister and Newbold, 2008). Complete elimination of ciliate protozoa from the rumen reduces methane emission by 30 to 45\% (Jouany et al., 1981; Itabashi et al., 1984; Ushida et al., 1986). If the effect is assumed to be linear, the 37 to $38 \%$ reduction in protozoal numbers that occurred for CS and SS would be expected to account for an 11 to $17 \%$ reduction in methane, or almost the entire observed reduction in methane. While these calculations likely overestimate the effect of reduced protozoal numbers, it can be concluded that the observed reduction in protozoal numbers likely accounted for a substantial portion of the methane reduction that occurred, particularly for the CS treatment where reduced digestibility was not a factor.

Ruminal $\mathrm{NH}_{3}-\mathrm{N}$ concentrations were expected to decrease with the reduction in protozoal numbers caused by oilseed supplementation, but that did not occur. Eliminating protozoa causes greater uptake of $\mathrm{NH}_{3}-\mathrm{N}$ caused by less intraruminal recycling of $\mathrm{N}$ and increased microbial protein synthesis (Oldick and Firkins, 2000). The lack of reduction in rumen $\mathrm{NH}_{3}-\mathrm{N}$ despite lower protozoal numbers that occurred in this study may have reflected the different protein sources used in the various diets to ensure similar RUP (35-38\%) and RDP levels. It is also possible that the higher rumen $\mathrm{NH}_{3}$ $\mathrm{N}$ concentration of the SS diet was caused by a lower ruminal digestible $\mathrm{OM}$ and associated lower bacterial uptake of $\mathrm{NH}_{3}-\mathrm{N}$ caused by lower microbial protein synthesis.

Yield of milk and its components were not affected by feeding oilseeds, probably because the cows were in midlactation and all diets were formulated to exceed energy and protein requirements of the cows. Future studies are needed to examine the potential effect of feeding oilseeds to reduce $\mathrm{CH}_{4}$ production on cow productivity. In our study, the calculated $\mathrm{NE}_{\mathrm{L}}$ values (Table 2) were lower for the SS diet, mainly because of slightly lower milk energy output and the lack of BW gain of these cows compared with cows fed the other diets. The lower calculated $\mathrm{NE}_{\mathrm{L}}$ value corresponded to the lower digestibility of this diet.

\section{CONCLUSIONS}

Adding crushed oilseeds to the diet of lactating dairy cows (supplying 3.7\% added fat) reduced daily $\mathrm{CH}_{4}$ production $(\mathrm{g} / \mathrm{d})$ by $13 \%$ compared with a control diet containing calcium salts of palm FA, with no differences among the types of oilseeds. However, the reduction in $\mathrm{CH}_{4}$ for SS and FS was either entirely (SS) or partially (FS) caused by a reduction in digestible DMI. In contrast, CS lowered $\mathrm{CH}_{4}$ without reducing digestible energy intake of the cows. Although milk production and milk efficiency were not affected by oilseed addition in this study, reduced digestible energy intake such as that which occurred when feeding FS and SS would be expected to lower milk production of high-producing dairy cows.

The study shows that adding oilseeds to the diet can be an effective means of reducing $\mathrm{CH}_{4}$ emissions. However, for some oilseeds the reduction in $\mathrm{CH}_{4}$ can be at the expense of diet digestibility with possible negative effects on milk production of high-producing dairy cows. Thus, the effects on milk production need to be evaluated in a wider context using cows in early lactation. Use of crushed CS offers a means of mitigating $\mathrm{CH}_{4}$ without negatively affecting diet digestibility and hence milk production, but this finding needs to be confirmed in subsequent studies. Although the results from this study supply evidence that $\mathrm{CH}_{4}$ emissions from the dairy sector can be reduced by adding oilseeds to the diet, the acceptance of adding FS and SS to diets by producers may not be as high as that for CS given the possible negative effect of FS and SS on milk production.

\section{ACKNOWLEDGMENTS}

We thank K. Andrews, T. Coates, B. Farr, and D. Vedres (all of Agriculture and Agri-Food Canada) for their invaluable technical assistance in conducting the experiment; T. Entz (Agriculture and Agri-Food Canada) for advice with the statistical analysis; the Lethbridge Research Centre farm staff for caring for the cows; and J.-S. Eun (currently at Utah State University) for a preliminary analysis of the data.

\section{REFERENCES}

AOAC. 1995. Official Methods of Analysis. 16th ed. Association of Official Analytical Chemists, Arlington, VA.

Beauchemin, K. A., M. Kreuzer, F. O'Mara, and T. A. McAllister. 2008. Nutritional management for enteric methane abatement: Aa review. Aust. J. Exp. Agric. 48:21-27. 
Beauchemin, K. A., S. M. McGinn, and H. V. Petit. 2007. Methane abatement strategies for cattle: Lipid supplementation of diets. Can. J. Anim. Sci. 87:431-440.

Boadi, D., C. Benchaar, J. Chiquette, and D. Massé. 2004. Mitigation strategies to reduce enteric methane emissions from dairy cows: Update review. Can. J. Anim. Sci. 84:319-335.

Bu, D. P., J. Q. Wang, T. R. Dhiman, and S. J. Liu. 2007. Effectiveness of oils rich in linoleic and linolenic acids to enhance conjugated linoleic acid in milk from dairy cows. J. Dairy Sci. 90:998-1007.

Canadian Council on Animal Care. 1993. Guide to the Care and Use of Experimental Animals. Vol. 1. 2nd ed. E. D. Olfert, B. M. Cross, and A. A. McWilliam, ed. CCAC, Ottawa, ON, Canada.

Cochran, R. C., D. C. Adams, J. D. Wallace, and M. L. Galyean. 1986. Predicting digestibility of different diets with internal markers: Evaluation of four potential markers. J. Anim. Sci. 63:14761483.

Dohme, F., A. Machmüller, A. Wasserfallen, and M. Kreuzer. 2000. Comparative efficiency of various fats rich in medium chain fatty acids to suppress ruminal methanogenesis as measured with RUSITEC. Can. J. Anim. Sci. 80:473-482.

Eugène, M., D. Massé, J. Chiquette, and C. Benchaar. 2008. Metaanalysis on the effects of lipid supplementation on methane production in lactating dairy cows. Can. J. Anim. Sci. 88:331334.

Finn, A. M., A. K. Clark, J. K. Drackley, D. J. Schingoethe, and T. Sahlu. 1985. Whole rolled sunflower seeds with or without additional limestone in lactating dairy cattle rations. J. Dairy Sci. 68:903-913.

Giger-Reverdin, S., P. Morand-Fehr, and G. Tran. 2003. Literature survey of the influence of dietary fat composition on methane production in dairy cattle. Livest. Prod. Sci. 82:73-79.

Grainger, C., T. Clarke, K. A. Beauchemin, S. M. McGinn, and R. J. Eckard. 2008. Supplementation with whole cottonseed reduces methane emissions and increases milk production of dairy cows offered a forage and cereal grain diet. Aust. J. Exp. Agric. 48:7376.

Grainger, C., T. Clarke, S. M. McGinn, M. J. Auldist, K. A. Beauchemin, M. C. Hannah, G. C. Waghorn, H. Clark, and R. J. Eckard. 2007. Methane emissions from dairy cows measured using the sulfur hexafluoride $\left(\mathrm{SF}_{6}\right)$ tracer and chamber techniques. J. Dairy Sci. 90:2755-2766.

Hess, B. W., G. E. Moss, and D. C. Rule. 2008. A decade of developments in the area of fat supplementation research with beef cattle and sheep. J. Anim. Sci. 86(E-Suppl. 1):E188-E204.

Hu, F. B., and W. C. Willett. 2002. Optimal diets for prevention of coronary heart disease. JAMA 288:2569-2578.

International Panel on Climate Change (IPCC). 2006. Revised IPCC Guidelines for National Greenhouse Gas Inventories. Workbook (Vol. 2), Module 4, Agriculture. http://www.ipcc-nggip.iges.or.jp/ public/2006gl/vol4.htm Accessed Nov. 12, 2008.

Itabashi, H., T. Kobayashi, and M. Matsumoto. 1984. The effects of rumen ciliate protozoa on energy metabolism and some constituents in rumen fluid and blood plasma of goats. Jpn. J. Zootech. Sci. 55:248-255.

Ivan, M., P. S. Mir, Z. Mir, T. Entz, M. L. He, and T. A. McAllister. 2004. Effects of dietary sunflower seeds on rumen protozoa and growth of lambs. Br. J. Nutr. 92:303-310.
Johnson, K. A., and D. E. Johnson. 1995. Methane emissions from cattle. J. Anim. Sci. 73:2483-2492.

Johnson, K. A., R. L. Kincaid, H. H. Westberg, C. T. Gaskins, B. K. Lamb, and J. D. Cronrath. 2002. The effect of oilseeds in diets of lactating cows on milk production and methane emissions. J. Dairy Sci. 85:1509-1515.

Jouany, J. P., B. Zainab, J. Senaud, C. A. Groliere, J. Grain, and P. Trivend. 1981. Role of the rumen ciliate protozoa Polyplastron multivesiculatum, Entodinium spp. and Isotricha prostoma in the digestion of a mixed diet in sheep. Reprod. Nutr. Dev. 21:871884

Kebreab, E., K. A. Johnson, S. L. Archibeque, D. Pape, and T. Wirth. 2008. Model for estimating enteric methane emissions from United States dairy and feedlot cattle. J. Anim. Sci. 86:2738-2748.

Machmüller, A., and M. Kreuzer. 1999. Methane suppression by coconut oil and associated effects on nutrient and energy balance in sheep. Can. J. Anim. Sci. 79:65-72.

Machmüller, A., C. R. Soliva, and M. Kreuzer. 2003. Methanesuppressing effect of myristic acid in sheep as affected by dietary calcium and forage proportion. Br. J. Nutr. 90:529-540.

Martin, C., J. Rouel, J. P. Jouany, M. Doreau, and Y. Chilliard. 2008. Methane output and diet digestibility in response to feeding dairy cows crude linseed, extruded linseed, or linseed oil. J. Anim. Sci. 86:2642-2650.

McAllister, T. A., and C. J. Newbold. 2008. Redirecting rumen fermentation to reduce methanogenesis. Aust. J. Exp. Agric. 48:7-13.

McGinn, S. M., K. A. Beauchemin, T. Coates, and D. Colombatto. 2004. Methane emissions from beef cattle: Effects of monensin, sunflower oil, enzymes, yeast, and furmaric acid. J. Anim. Sci. 82:3346-3356.

Monteny, G.-J., A. Bannink, and D. Chadwick. 2006. Greenhouse gas abatement strategies for animal husbandry. Agric. Ecosyst. Environ. 112:163-170.

NRC. 2001. Nutrient Requirements of Dairy Cattle. 7th rev. ed. National Research Council, Washington, DC.

Ogimoto, K., and S. Imai. 1981. Page 158 in Atlas of Rumen Microbiology. Japan Sci. Soc. Press, Tokyo, Japan.

Oldick, B. S., and J. L. Firkins. 2000. Effects of degree of fat saturation on fiber digestion and microbial protein synthesis when diets are fed twelve times daily. J. Anim. Sci. 78:2412-2420.

Rhine, E. D., G. K. Sims, R. L. Mulvaney, and E. J. Pratt. 1998. Improving the Berthelot reaction for determining ammonium in soil extracts and water. Soil Sci. Soc. Am. J. 62:473-480.

SAS Institute. 2001. System for Windows Release 9.1. SAS Inst. Inc., Cary, NC.

Ushida, K., A. Miyazaki, and R. Kawashima. 1986. Effect of defaunation on ruminal gas and VFA production in vitro. Jpn. J. Zootech. Sci. 57:71-77.

Van Soest, P. J., J. B. Robertson, and B. A. Lewis. 1991. Methods for dietary fiber, neutral detergent fiber, and nonstarch polysaccharides in relation to animal nutrition. J. Dairy Sci. 74:3583-3597.

Woodward, S. L., G. C. Waghorn, and N. A. Thomson. 2006. Supplementing dairy cows with oils to improve performance and reduce methane-Does it work? Proc. N.Z. Soc. Anim. Prod. $66: 176-181$. 